\title{
Laboratory Rearing of the Amami Rabbits (Pentalagus furnessi Stone, 1900) in Captivity
}

\author{
Tetsuya MATSUZAKI, Hiroshi SUZUKI*, and Masao KAMIYA** \\ Central Institute for Experimental Animals, 1430, Nogawa, Miyamae, \\ Kawasaki 213, Japan, * Department of Virology, Institute for \\ Toropical Medicine, Nagasaki University, Nagasaki 852, and \\ ** Depatment of Parasitology, Faculty of Veterinary \\ Medicine, Hokkaido University, Sapporo 060.
}

(Received 26 January 1988/Accepted 16 September 1988)

\begin{abstract}
Five Amami rabbits in each sex were firstly introduced into the Central Institute for Experimental Animals. The authors intended to breed the Amami rabbits in the laboratory. During breeding, the Amami rabbits were nervous to external stimuli, easily frightend and always showed escaped behaviour. They were given pelleted foods for rabbits and pikas and also. given apples and sweet potatos as additional foods. The Amami rabbits were showed to practice coprophagy in the same way as laboratory rabbits. After introduction, they required 13 months to reach the maximum body weights which were $2.73 \mathrm{~kg}$ for females and $2.71 \mathrm{~kg}$ for males. Matings were attempted with one female and one male in newly deviced reproductive cages. By seventy four matings, one pregnancy was produced and one child was delivered. This neonate ( 2 day old $)$ had closed eyes and ears, incisors and brown short hair and weighed $100 \mathrm{~g}$. Unfortunately, the pup was died on the 4 th day. The body length of this stage was $15 \mathrm{~cm}$.
\end{abstract}

The Amami rabbits (Pentalagus furnessi) belong to Leporidae, Palaeolaginae, together with volcano rabbits (Romerolagus diazi) [3, 6 , 7] and rock hares (Pronolagus spp.) $[3,12]$. Their habitat is limited to the Amami-Oshima island, one of the Seinan islands which locate the south of the Japanese archipelago. The Amami rabbits are internationally protected speciesand designated as a natural monument in Japan.

Artificial breeding of the Amami rabbits has been attempted in outdoors on AmamiOshima island in 1962 [8] and also at the Hirakawa Zoo in Kagoshima in 1980 [11]. However, there have been no reports of studies on the laboratory breeding of these animals. The authors have succeeded in the Laboratory breeding of pikas [9] and volcano rabbits [10]. Therefore, we intended to breed the Amami rabbits in the laboratory on the basis of the experience with the volcano rabbits.
Animals : Five male and five female Amami rabbits were captured in April and June, 1984, with the permission of the Agency for Cultural Affairs and the Environment Agency of Japan. These animals were firstly introduced into the Central Institute for Experimental Animals (CIEA)in April, 1984[4, $5]$.

Animal room : The animal room was kept at a temperature of $22 \pm 2{ }^{\circ} \mathrm{C}$ and a humidity of $55 \pm 5 \%$. Air was changed 10-15 times/hour with fresh air. Lights were kept on from $6: 00$ to $20: 00$. Since the animals were active during night, an 8 lux electric light was kept on.

Cages: The animals were cared with rabbit reproductive cages (CLEA Japan, Inc Model CR- II, $\left.75^{\mathrm{W}} \times 50^{\mathrm{D}} \times 35^{\mathrm{H}} \mathrm{cm}\right)$ one by one. Each cage was divided into two parts with a partition which had an opening to pass through. One part of the cage was covered with an aluminum plate to keep dark. This served as a 
Table 1. Amounts of feces excreted by Amami and NZW III/J rabbits

\begin{tabular}{|c|c|c|c|}
\hline & Amami rabbits & NZW III / J rabbits & $\begin{array}{l}\text { Significant } \\
\text { differences }\end{array}$ \\
\hline Females & $\mathrm{n}=5$ & $\mathrm{n}=5$ & \\
\hline Body weight & $2.18 \pm 0.12$ & $3.73 \pm 0.37$ & $\mathrm{P}<0.001$ \\
\hline \multicolumn{4}{|l|}{ Amount of feces } \\
\hline (g/day/animal) & $53.8+22.8$ & $96.8 \pm 31.7$ & $\mathrm{P}<0.05$ \\
\hline (g/day/ kg of body weight) & $24.7 \pm 10.6$ & $26.5 \pm 10.2$ & NS \\
\hline \multicolumn{4}{|l|}{ No. of feces } \\
\hline (day/animal) & $207.7 \pm 51.3$ & $375.5 \pm 58.3$ & $\mathrm{P}<0.01$ \\
\hline (day/kg of body weight) & $95.5 \pm 26.2$ & $101.2 \pm 16.5$ & NS \\
\hline Males & $\mathrm{n}=5$ & $\mathrm{n}=5$ & \\
\hline Body weight & $2.13 \pm 0.27$ & $3.50 \pm 0.08$ & $\mathrm{P}<0.001$ \\
\hline \multicolumn{4}{|l|}{ Amount of feces } \\
\hline (g/day/animal) & $50.2 \pm 28.6$ & $112.8 \pm 24.1$ & $\mathrm{P}<0.01$ \\
\hline (g/day/ kg of body weight) & $23.7 \pm 13.1$ & $32.1 \pm 6.6$ & NS \\
\hline \multicolumn{4}{|l|}{ No. of feces } \\
\hline (day/animal) & $176.3 \pm 67.4$ & $388.9 \pm 52.6$ & $P<0.001$ \\
\hline (day/kg of body weight) & $84.5 \pm 35.9$ & $111.0 \pm 14.4$ & NS \\
\hline
\end{tabular}
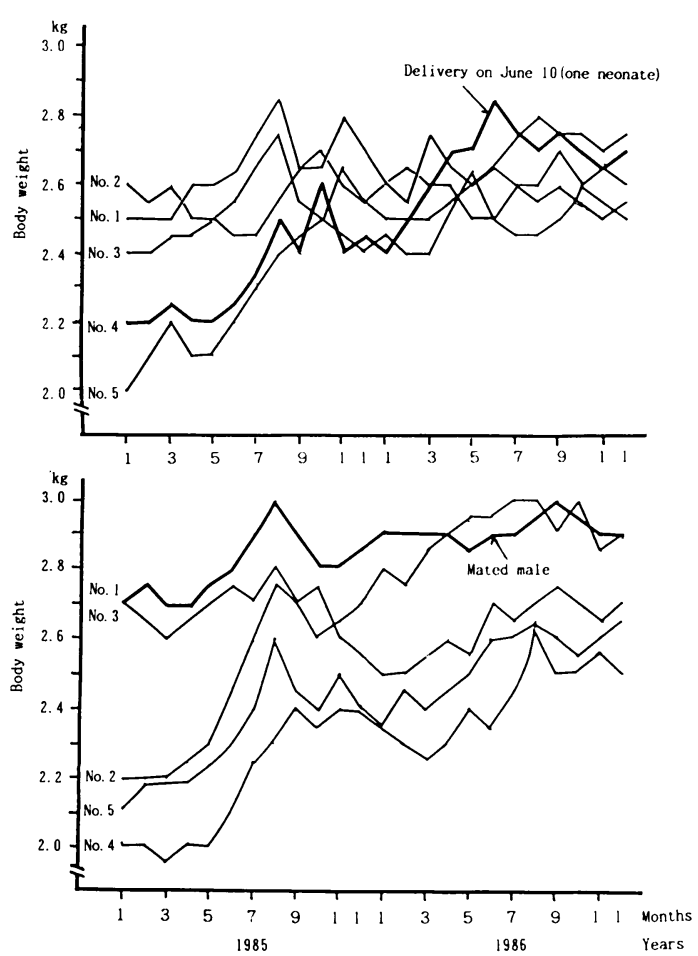

Fig. 1. Changes in body weights of male and female Amami rabbits during laboratory rearing Top:females Bottom: males

hiding area for the animals. The bright half was a feeding area. For reproduction, a single cage $210 \mathrm{~cm}$ wide was newly devised by joining six cages in parallel. Delivery areas containing bedding were arranged for both ends of cage and a feeding area in the center.

Food: At the introduction, the rabbits were mainly given grasses or weed.

From many trials, the Amami rabbits were mainly given pellted food for rabbits (CR-3, CLEA Japan Inc.) and pika (CIEA-117) and additionally given sweet potatoes and apples.

Coprophagy: It was observed that the Amami rabbits practiced coprophagy in the same way as domestic rabbits, pikas and volcano rabbits. There were two feces types, solid, round feces with high fiber contents and soft glossy feces encased in a thin layer mucus. The animals took the latter.

Amount of excreted feces : Table 1 shows the amount of excreted solid feces of the Amami rabbits compared with NZW III / J rabbits. There were not significant differences in amounts and numbers of excreted feces $(\mathrm{g} / \mathrm{Kg}$ body weight/day/head) in both sexes as compared with NZW III /J rabbits. It is considered that the Amami rabbits are in good health conditions.

Changes in body weights : After introduction, most rabbits were decreased in body weight as compared with that of capture. However, they recovered after about one month (data not shown).

Fig. 1 shows the changes in body weight 
Table 2. Number of attempted matings of Amami rabbits (1985-1986)

\begin{tabular}{|c|c|c|c|c|c|c|c|}
\hline \multicolumn{2}{|c|}{ Females } & No. 1 & No. 2 & No. 3 & No. 4 & No. 5 & Total \\
\hline \multirow{5}{*}{ Males } & No. 1 & 2 & 4 & 2 & $7^{*}$ & 6 & 21 \\
\hline & No. 2 & 2 & 7 & 3 & 3 & 4 & 19 \\
\hline & No. 3 & 2 & 2 & 1 & 2 & 2 & 9 \\
\hline & No. 4 & 3 & 1 & 4 & 2 & 1 & 11 \\
\hline & No. 5 & 5 & 2 & 1 & 3 & 3 & 14 \\
\hline \multicolumn{2}{|l|}{ Total } & 14 & 16 & 11 & 17 & 16 & 74 \\
\hline
\end{tabular}

* Pairing achieving pregnancy

measured monthly over 2 years. Among 10 rabbits, No. 1 female was the heaviest and oldest. Body weight in No. 3 male increased most markedly, and followed in the order of No. 4 female, No. 5 male and Nos. 2 and 5 females. Remaining rabbits were gradually increased in their body weights. All of these rabbits were considered to be young and in good growth. The maximum body weights (mean of 5 rabbits in each sex) were observed in August, 1985, $2.73 \mathrm{Kg}$ for females and 2.71 $\mathrm{Kg}$ for males. There was not a sex difference in body weight.

Mating attempts : Matings were attempted from 3 months after introduction Pairs were selected at random. When females were introduced into the male cages many males approached females and lifted low abdomen of female with tip of his nose. Sometimes, males bit the legs of female. Cohabitations were practiced with a short period (1-7 days)or a long period (1-3 months). When hair losts or wounds were observed, they were separeted on the day or next morning. Diagnosis of pregnancy was practiced by palpation.

As shown in Table 2, of 74 times cohabitation, one pregnancy, cohabited with No. 4 female and No. 1 male, was confirmed by palpation. One child was observed in a nest which was $15 \mathrm{~cm}$ diameter and $5 \mathrm{~cm}$ depth (Fig. 2). The neonate with $100 \mathrm{~g}$ body weight had short brown hair, closed eyes and ears, incisors, nails and theree pairs of nipples. Unfortunately, the neonate was died on the 4 th day after delivery (Fig. 3). Table 3 shows the results of measurement of various sites of the died neonate.

Crandall [1] have been attempted to breed wild hares, but they moved around very much and were difficult to handle. Hediger [2] have pointed out that hares are very timid and easily frightened, and are often infected with parasites. For these reasons, it is very difficult

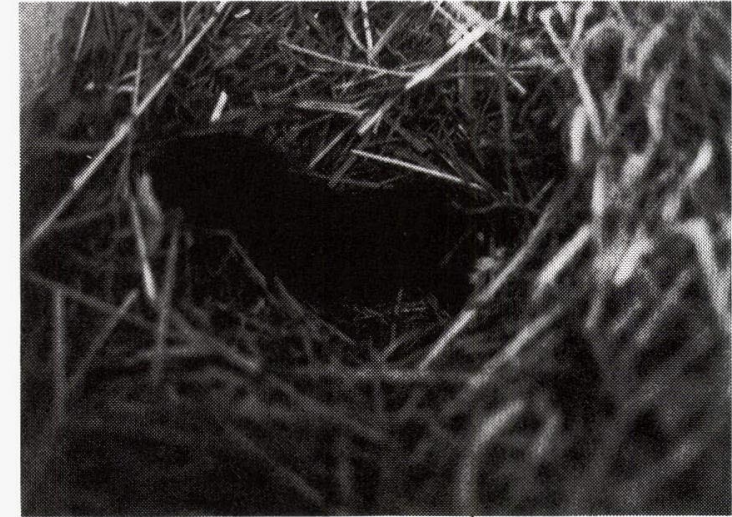

Fig. 2. Two days old neonate of the Amami rabbit

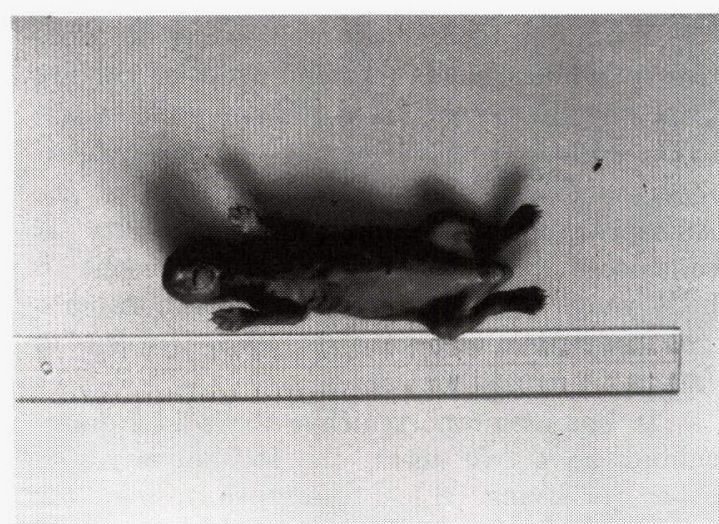

Fig. 3. The Amami rabbit which was died on the 4 th day after birth

to breed hares artificially in the open.

In an atempt to breed the Amami rabbits in the open at Hirakawa Zoo, it has been reported that eight of 10 rabbits were died due to fighting among themselves and parasitosis [8]. At the time of capture, trombiculid mites and ticks were observed and also observed highly infective parasites (Eimeria spp, Obeliscoides pentalagi and Heligmonella leposis) [4, 5]. These external and internal palasites were prevented by providing a wire mesh floring to 
Table 3. Lengths of various sites of the 4-day-old neonate

\begin{tabular}{lr} 
Body length* & $15.0 \mathrm{~cm}$ \\
Head length & $4.0 \mathrm{~cm}$ \\
Ear length & $1.5 \mathrm{~cm}$ \\
Tail length & $0.5 \mathrm{~cm}$ \\
Fore limb length & $1.5 \mathrm{~cm}$ \\
Hind limb length & $3.0 \mathrm{~cm}$ \\
\hline
\end{tabular}

* From tip of nose to site of tail attachment

keep cages clean, changing cages of ten and autoclaving equipments. It is considered that laboratory breeding is more useful than outdoor breeding as a method for artificial rearing of wild rabbits.

During breeding, the Amami rabbits were given pelleted food for rabbits and pikas and, apples and sweet potatoes as additional foods. Excretions of feces were not different from that of NZW III /J rabbits (Table 1). It is suggested that the Amami rabbits were in good food intakes and in good health conditions. However, these foods may not be considered nutritionally enough for the Amami rabbits. It will be necessary to develop a new food for them near future.

From our experiences of breeding on laboratory rabbits, pikas [9] and volcano rabbits $[10]$, they were considered to be in good conditions judging from variations of body weight, feces condition and external profiles of the Amami rabbits. Although the maturity is considered to be terminating of increment in body weight, maturity of the Amami rabbits was considered to be August, $1985,2.5-3.0 \mathrm{~kg}$ (mean $2.7 \mathrm{~kg}$ ) in both sexes.

It has been reported that the wild Amami rabbits have two nests, one for delivery and other for living [8]. Therefore, a cage for reproduction was newly devised. In a total of 74 matings, one pregnancy was obtained and one child was delivered. Birth of the Amami rabbit in the laboratory is the first time in the world. Unfortunately, the neonate was died on the 4 th day after parturition. The reason why the neonate was not nursed is considered to be the nest different from that in wild, irritation of the mother due to handle the neonate or lack of nursing ability of the mother.

Indoor reproduction of the Amami rabbits will be achieved in the near future through improving the breeding conditions including animal rooms, rations, cages and nests.

The authors wish to thank Drs. T. Nomura, Y. Tajima, M. Sasa, K. Nakayama, S. Kuboniwa, J. Shinada, A. Nawa, and $\mathrm{S}$. Hattori for their kind supports and understandings and also wish to thank Mrs. Z. Hajime, T. Minami, I. Sato, Z. Noboru for their coorporation in the capture of the Amami rabbits in the Amami-Oshima island.

\section{References}

[1] Crandall, L. S. (1963). Management of Wild Mammals in Captivity, pp.203-204. The University of Chicago Press, Chicago \& London.

[2] Hediger, H. (1964). Wild Animals in Captivity, pp. 138-142. Dover, New Yok.

[3] Kamiya, M. (1978). Modern media, 24, 250-260. (in Japanese).

[4] Kamiya, M., Fukumoto, S., Matsuzaki, T., and Suzuki, H. (1987). Hokkaido J. vet. Sci. Ass., 31, 221228. (in Japanese).

[5] Kamiya, M., Fukumoto, S., Matsuzaki, T., and Suzuki, H. (1987). Hokkaido J. vet. Sci. Ass., 31, 241247. (in Japanese).

[6] Kamiya, M., Matsuzaki, T., and Suzuki, H. (1987). Study of Animal Sciense, 42, 17-21. (in Japanese).

[7] Kamiya, M., Matsuzaki, T., and Suzuki, H. (1987). Study of Animal Sciense, 42, 31-34. (in Japanese).

[8] Kirino, M. (1977). Series : Wild Animals in Japan, Life fossil-Amami rabbit. Tyobunsya, Tokyo. (in Japanese).

[9] Matsuzaki, T., Saito, M., Yamanaka, M., Esaki, K., and Nomura, T. (1980). Exp. Anim 29, 165-170. (in Japanese).

[10] Matsuzaki, T., Kamiya, M., and Suzuki, H. (1985). Exp. Anim 34, 63-66.

[11] Sakou, T. (1985). Open rearing of the Amami rabbits in Hirakawa Zoo, Nature Conservation Bureau Environment Agency Japan. (in Japanese).

[12] Suzuki, H. (1979). JPN Sci. Month., 32, 66 (in Japanese). 


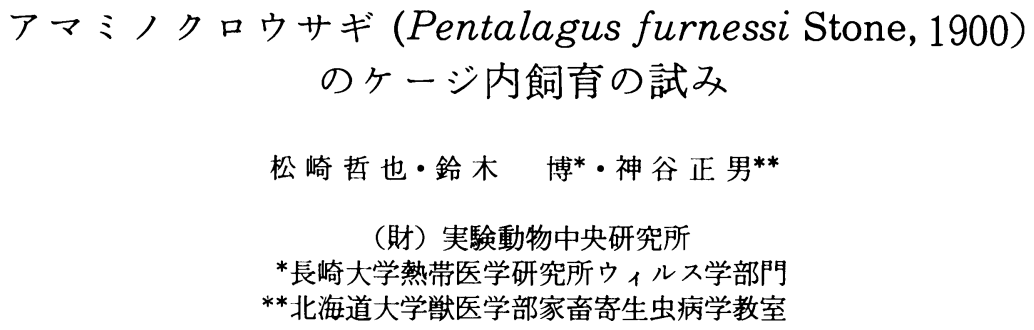

1984年 4 月から 6 月にかけて奄美大島で捕獲したアマ ミノクロウサギ (Pentalagus furnessi, 以下クロウサ ギと略す）雙雄各 5 匹を導入し, ケージ内飼育・繁殖を 試みた。飼育中のクロウサギは神経質で音に敏感で警戒 心が強く，常に逃避行動をしめした。飼料は，ウサギお。 よびナキウサギ用の固形飼料を主に，好食するサッマイ モ，リンゴ，ススキ等の野草を若干与えた。クロウサギ はカイウサギと同じく食翼行動がみられた。翼には硬い 翼と軟らかい資の 2 種があり，後者を食した。ケージ内 飼育のクロウサギは最大体重に達するまでに13力月を要 したが，雌雄間に体重の差はみられなかった。繁殖には
小型のケージ 6 個を並列に並べた 6 連式ケージを作製し て用いた。交配は雌雄 $1:$ : 1 で行った。雌雄各 5 匹の種 々の組み合わせで，延べ74回の交配を試みた。そのらち の 1 組に妊娠が成立し，1986年 6 月 10 日， 1 仔の誕生を

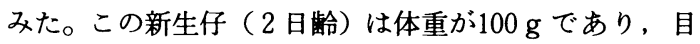
や耳が閉じ，閒歯が萌出していた。また，新生仔は野生 色の短毛を有しており，腹部の皮㲊は赤味を帯びてい た。4肢の爪は伸びて, 先端は白く糸状に巻いていた。 新生仔は生後 4 日で死亡したが, この時の体長は $15 \mathrm{~cm}$ であった。 